\title{
PENINGKATAN USAHA MELALUI DIVERSIFIKASI PRODUK KERAJINAN TENUN KUBANG KABUPATEN LIMA PULUH KOTA
}

\author{
Nelson Elita*1, Darnetti $^{2}$, Harmailis ${ }^{3}$ \\ ${ }^{1,2}$ Raya Negara Street Tanjung Pati Lima Puluh Kota DISTRICT West Sumatra (26271) \\ ${ }^{3}$ Study Program of Cultivation of Food Crops State Polytechnic Payakumbuh \\ E-mail: nelsonelita@yahoo.com
}

\begin{abstract}
Minangkabau people call themselves civilized people and show glory and dignity using woven fabrics. This condition makes weaving crafts as a home industry and raises the Small and Medium Enterprises (SMEs) group in Nagari Kubang Regency, Lima Puluh Kota.Small and Medium Enterprises (SME) Marni Geneng and CV Rangkiang are partners of PPUD Minangkabau Weaving Crafts in Kubang Nagari, Lima Puluh Kota District. The two SME agreed to partner in PPUD activities organized by the Payakumbuh State Agricultural Polytechnic Team in order to move towards the foreign export market.

The goal in the PPUD program for these two SME is to increase the value of turnover, assets, increase the number and quality of products and expand the product market so that opportunities for exports are increasingly open.Coaching methods for partner SME include lectures, discussions, training, demonstrations, mentoring and program evaluation. Lectures, discussions, demonstrations and training were carried out to diversify woven products. Furthermore, assistance is provided for all topics that have been given.The success of the program is that the PPUD team evaluates. Assistance carried out by the PPUD service team to UKM Kubang weaving partner partners, was able to increase turnover through the diversification of products produced.
\end{abstract}

Keywords - Woven, Minangkabau, Marni Geneng, Rangkiang

\begin{abstract}
Abstrak
Orang Minangkabau menyebut diri mereka sebagai orang beradat dan menunjukkan kemuliaan derajat serta martabat memakai kain tenun. Kondisi ini menjadikan kerajinan tenun sebagai industri rumah tangga dan memunculkan kelompok Usaha Kecil dan Menengah (UKM) di Nagari Kubang Kabupaten Lima Puluh Kota. Kelompok Usaha Kecil dan Menengah (UKM) Marni Geneng dan CV Rangkiang adalah mitra dari PPUD Kerajinan Tenun Minangkabau di Nagari Kubang Kabupaten Lima Puluh Kota. Kedua UKM ini sepakat untuk bermitra dalam kegiatan PPUD yang diselenggarakan oleh Tim Pengabdian Politeknik Pertanian Negeri Payakumbuh dalam rangka menuju pasar ekspor luar negeri. Tujuan dalam program PPUD pada kedua UKM ini adalah meningkatkan nilai omset, aset, peningkatan jumlah dan mutu produk serta memperluas pasar produk sehingga peluang untuk ekspor semakin terbuka. Metode pembinaan kepada UKM mitra meliputi ceramah, diskusi, pelatihan, demonstrasi, pendampingan dan evaluasi program. Ceramah, diskusi, demonstrasi dan pelatihan dilakukan untuk diversifikasi produk berbahan dasar tenun. Selanjutnya dilakukan pendampingan untuk semua topik yang sudah diberikan. Keberhasilan program maka tim PPUD melakukan evaluasi. Pendampingan yang dilakukan tim pengabdian PPUD kepada UKM mitra pengrajin tenun Kubang, mampu meningkatkan omset melalui diversifikasi produk yang dihasilkan.
\end{abstract}

Kata kunci-Kerajian tenun, Minangkabau, Marni Geneng, Rangkiang

\section{PENDAHULUAN}

Pengertian tenun yakni proses pembuatan kain yang terbuat dari benang yang disebut lusing, benang tersebut dicelupkan ke pewarna terlebih dahulu sebelum akhirnya diikat atau dirajut 
secara selang seling menjadi sebuah helaian kain. Tenun juga dapat diartikan sebagai proses pembuatan kain yang dilakukan menggunakan mesin sederhana dan dibuat masih sangat tradisional yang banyak menggunakan tenaga manusia sebagai penggeraknya.

Arti tenun menurut kamus bahasa Indonesia adalah proses pembuatan sehelai kain dengan cara memasukkan benang pakan kedalam lusing. Sesuai dengan kebutuhan manusia atas bahan sandang aktivitas menenun mulai tersebar ke berbagai tempat di dunia. Penyebarannya merata meliputi benua Eropa, Amerika hingga ke Asia, dan akhirnya masuk ke wilayah Indonesia. Di Indonesia sendiri tenun juga mengalami penyebaran hingga ke pelosok daerah dan hampir disemua tempat memiliki produksi tenun yang unik dan berkualitas (Kartiwa, 1998).

Menurut beberapa kolektur tenun dunia asal Amerika Serikat dan Kanada, Sumatera memiliki potensi besar untuk dapat menjadi daerah tujuan wisata kain tenun dunia. Hal ini didasarkan pada kekayaan motif tenun juga semata-mata produksi tenun yang terdapat di pulau tersebut. Didaerah Sumatera, beberapa tenun yang terkenal antara lain adalah tenun Pandai Sikek dan Silungkang dari Sumatera Barat, tenun songket Jambi, tenun Melayu, Toba dan Simalungun, Pakpak dari Sumatera Utara dan lain-lain.

Bagi orang Minangkabau yang menyebut diri mereka sebagai orang beradat, kain tenun adalah bagian yang tidak bisa dipisahkan dari upacara-upacara adat istiadat. Ditinjau dari bahan, cara pembuatan, dan harganya, menunjukkan kemuliaan derajat dan martabat pemakainya. Akan tetapi, kini bahan tenun seperti songket tidak hanya dimaksudkan untuk golongan masyarakat kaya dan berada semata, karena harganya yang bervariasi. Meskipun demikian, songket kualitas terbaik tetap dihargai sebagai bentuk kesenian yang anggun dan bernilai budaya tinggi.

Dikabupaten Lima Puluh Kota khususnya di Nagari Kubang sudah lama terkenal dengan Tenunan Kubang. Masyarakat didaerah ini menjadikan tenunan sebagai pekerjaan utama, berbagai bentuk hasil kerajian seperti kain songket, sarung, bahan pakain dengan berbagai motif mencirikan adat Minangkabau di produksi disini.

Sejalan dengan berjalannya waktu perubahan hasil tenun dan kerajinan yang ada saat ini umumnya merupakan perubahan dari pengaruh besar atau kecil kehidupan manusia. Bahan tenun sudah banyak dimodifikasi sehingga menghasilkan diversifikasi produk. Perubahan tersebut diiringi dengan inovasi-inovasi yang terjadi sesuai dengan kebutuhan manusia saat ini. Tenunan Kubang sudah mengalami inovasi semenjak tim PPUD Politeknik Pertanian Negeri Payakumbuh melalukan pengabdian pada UKM mitra seperti baju stelan wanita, baju gamis, rok dan blus, untuk laki-laki berkembang dengan baju tenun semi jas, baju koko, sarung. Diversifikasi dari produk tenun telah di produksi berupa asesoris seperti mainan kunci, dompet tempat meletakkan hand phone, taplak meja, sarung galon air, sarung bantal kursi dan lain-lain. Kondisi ini menjadikan kerajinan tenun Kubang sebagai primadona sehingga Pemerintah Daerah Kabupaten Lima Puluh Kota mengangkat menjadi Produk Unggulan Daerah . Kabupaten Lima Puluh telah mencanangkan tenunan Kubang sebagai Produk Unggulan Daerah yang ke empat diantara produk unggulan daerah lainnya, seperti terlihat pada Gambar 1

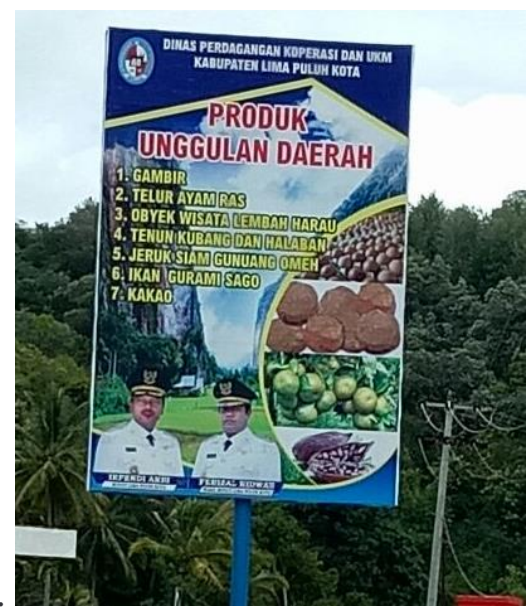

Gambar 1. Tenun Kubang termasuk produk Unggulan Daerah ke 4 di Kabupaten Lima Pupuh Kota. 


\section{METODE}

Metode pembinaan kepada UKM mitra meliputi ceramah, diskusi, pelatihan, demonstrasi melalui penambahan alat tenun bukan mesin, pendampingan mengunjungi ivent carnaval dan evaluasi program. Ceramah, diskusi, demonstrasi dan pelatihan dilakukan untuk diversifikasi produk berbahan tenun. Selanjutnya dilakukan pendampingan mengunjungi ivent carnaval SISCA yang diadakan oleh Pemda Kota Sawahlunto. Untuk melihat keberhasilan program maka tim melakukan evaluasi mulai dari awal sampai akhir kegiatan.

\section{HASIL DAN PEMBAHASAN}

\section{Penambahan Alat Tenun Bukan Mesin}

Program Pengembangan Produk Unggulan Daerah (PPPUD) memberikan inovasi dengan penambahan Alat Tenun Bukan Mesin (ATBM). Penambahan alat ini berdasarkan dari pelaksanaan pelatihan yang sudah dilakukan bagi anggota UKM sehingga UKM mampu menghasilkan produk tenun pakaian 3 lembar/2 hari . Alat yang lama hanya mampu menghasilkan 1 lembar/hari.

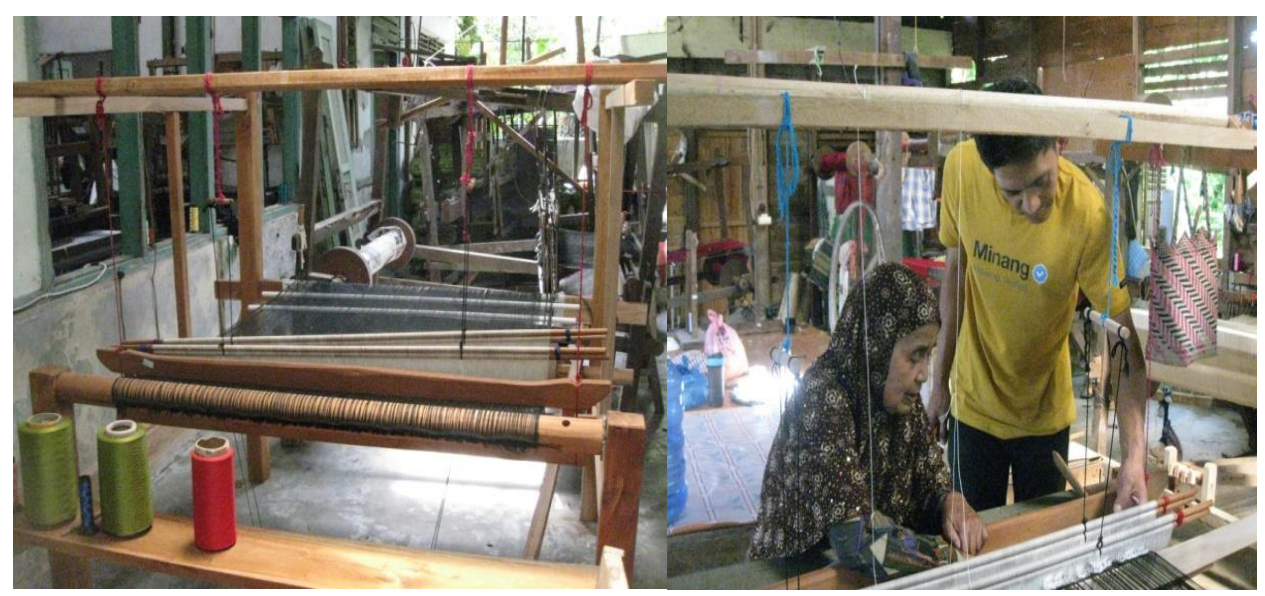

Gambar 1. Alat tenun ATMB untuk kedua UKM mitra

Kain tenun yang dihasilkan dari ATBM ini menjadikan produk tenun UKM mitra Kubang lebih cantik Gambar 2. Stelan kain kebaya yang lebih menarik.

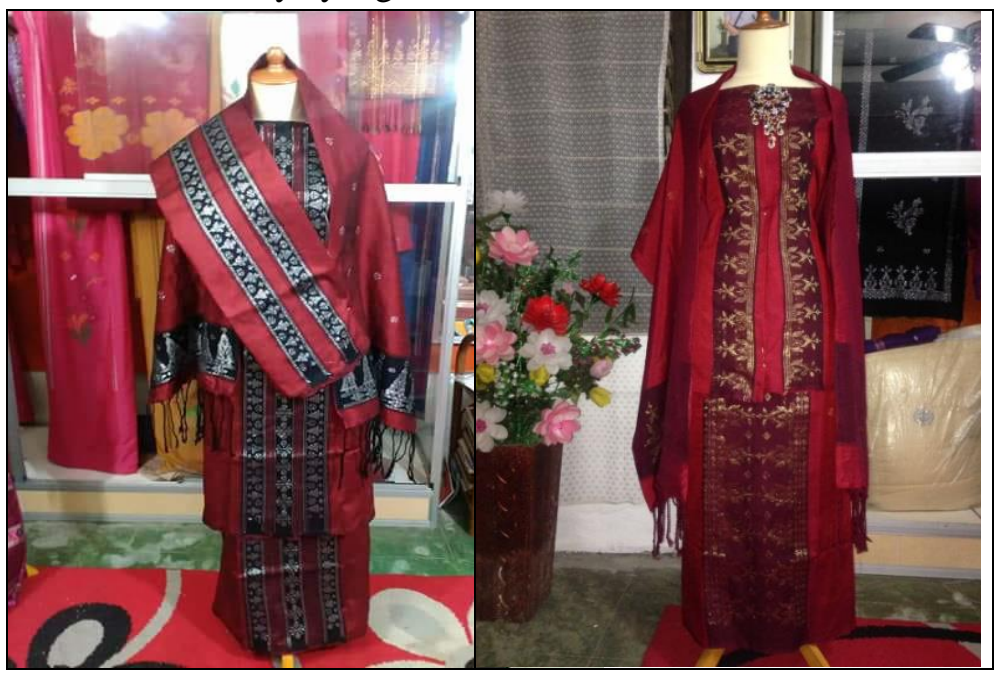

Gambar 2. Stelan baju tenun hasil ATBM yang baru.

Hasil pelatihan pengembangan motif adanya desain motif tabur yang di perbarui. Pada produk tenun yang lama jarak bunga tabur lebih jauh sehingga sering terpotong ketika di jadikan 
baju. Ukuran motif bunga tabur juga di perbesar. Produk yang dihasilkan sesudah pelatihan jarak bunga tabur lebih dekat. Selain itu motif bunga diberi benang maccao sehingga motif menjadi timbul dan lebih menarik.
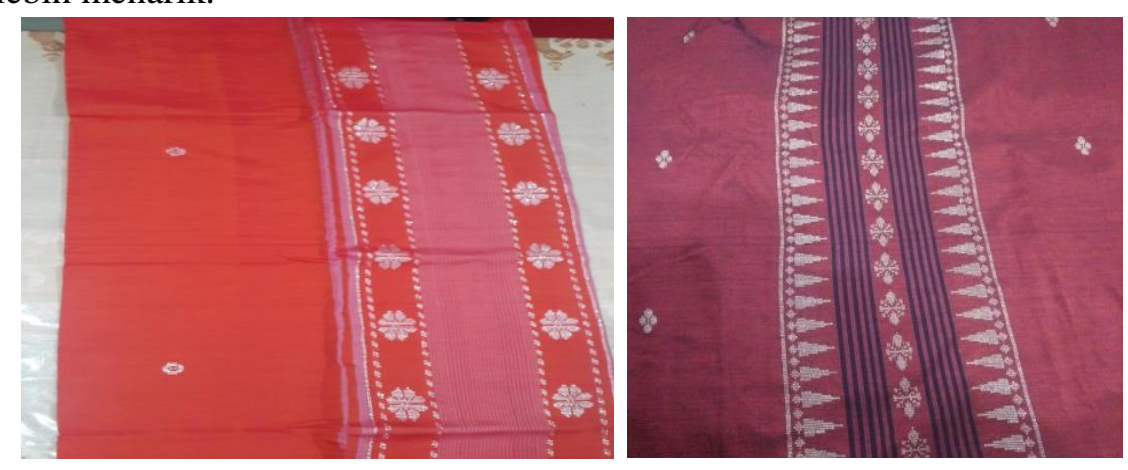

Gambar 3. Hasil desain yang baru dengan jarak motif tabur yang lebih dekat

Produk tenun ini sudah di modifikasi dengan sulaman sehingga nilai kain tenun lebih menarik lagi seperti dilihat pada Gambar 4.

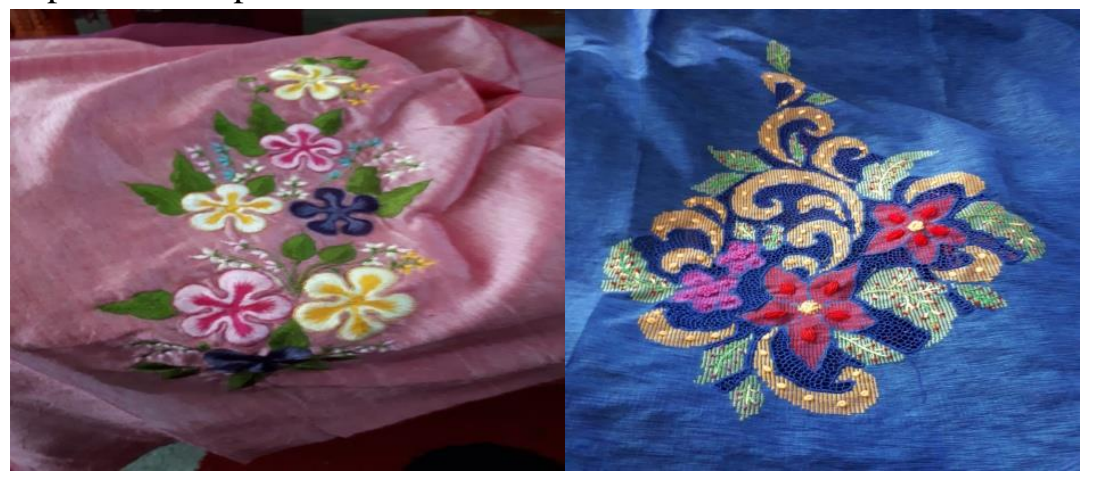

Gambar 4. Desain tenun yang dimodifikasi dengan sulaman

\section{Produk-Produk Berbahan Dasar Tenun}

Produk yang dihasilkan oleh UKM mitra berupa kain tenun pakaian wanita, gamis, baju kurung, rok dan blus, stelan untuk kebaya perempuan, baju laki-laki, sarung, juga dihasilkan diversifikasi produk dari sisa tenun yang sebelumnya ini tidak dapat memanfaatkan hasil sampingan tenun berupa tas kecil tempat hand phone, maian kunci, tempat tissue, penutup galon dan tas kain (Gambar 4, 5, 6, 7, 8 dan 9 ).

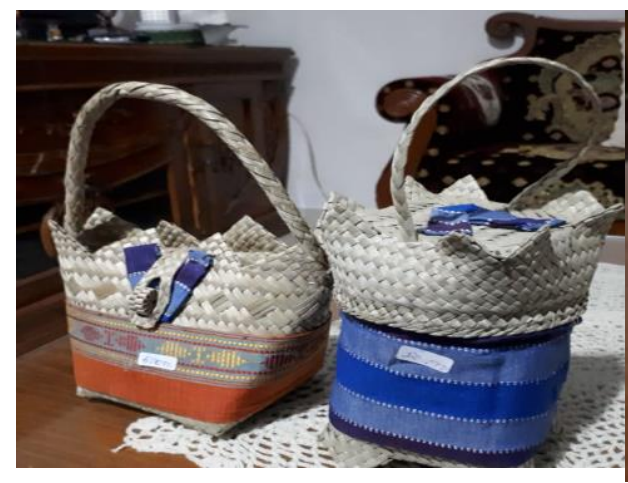

Gambar 4.Tas kecil tempat HP

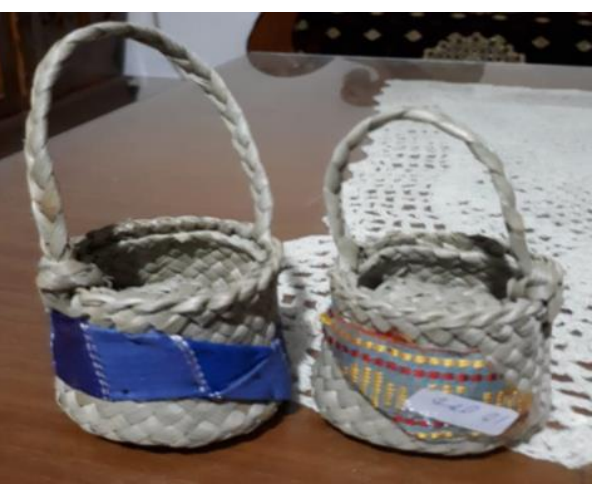

Gambar 5. Mainan kunci 


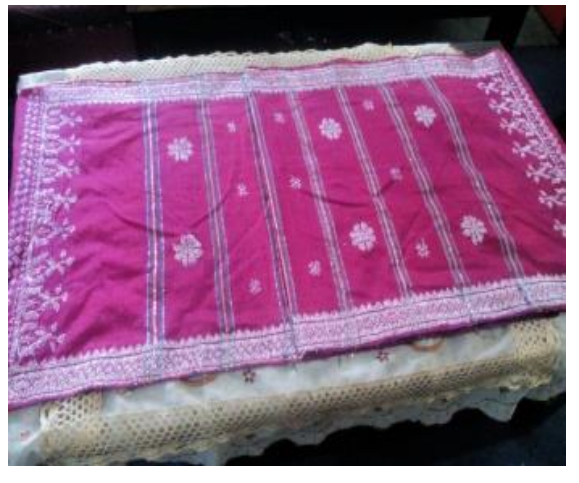

Gambar 6. Alas Meja

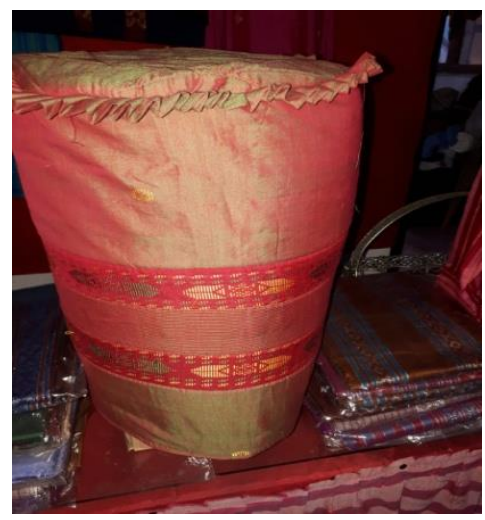

Gambar 8. Penutup galon air

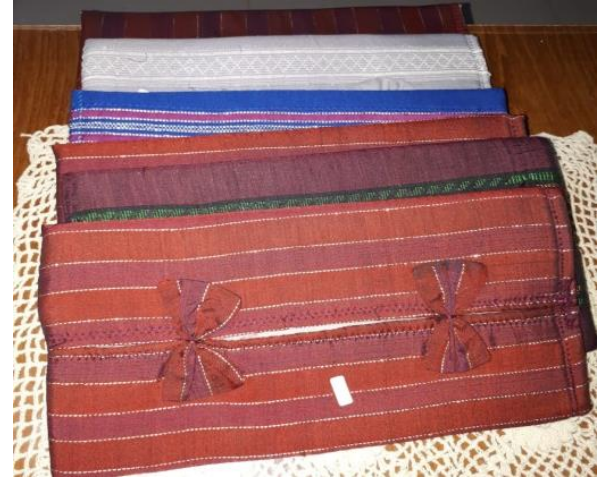

Gambar 7. Tempat tissu

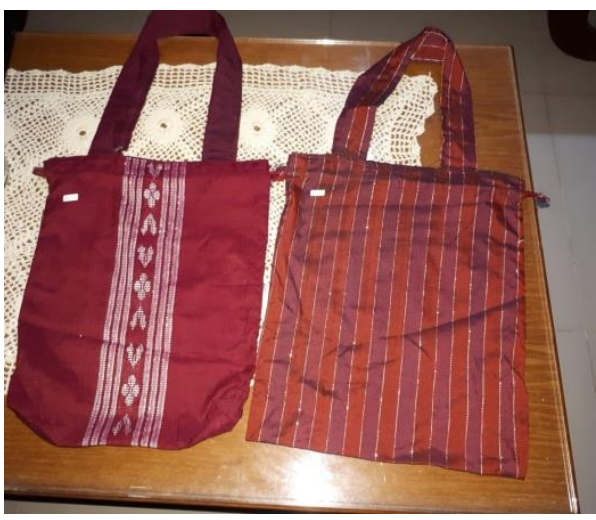

Gambar 9. Tas kain

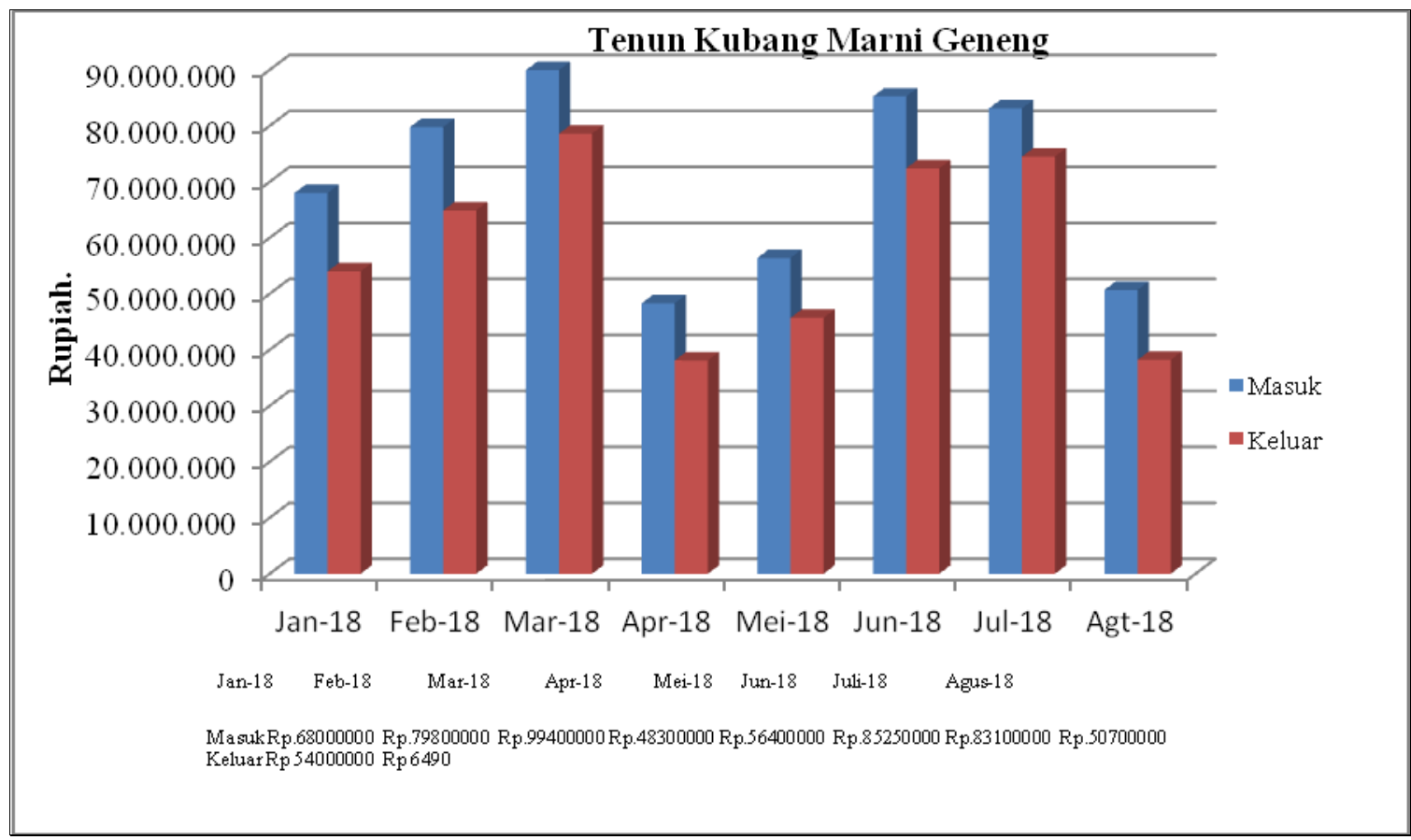

Gambar 10. Arus kas dari mitra Tenun Kubang Marni Geneng

Arus kas UKM mitra dari bulan Januari sampai Agustus 2018 menunjukkan kenaikan yang cukup tajam. Kenaikan omset juga disebabkan adanya varian produk tenun yang sudah 
diproduksi oleh mitra, yaitu tas tempat hand phone, mainan kunci, alas meja, tempat tissu, penutup gallon air dan tas kain yang kecil. Semua produk ini berbahan baku tenun Kubang.

\section{KESIMPULAN}

Pendampingan yang dilakukan tim pengabdian PPUD dari Politeknik Pertanian Negeri Payakumbuh kepada UKM mitra pengrajin tenun Kubang, mampu meningkatkan omset melalui diversifikasi produk yang dihasilkan.

\section{SARAN}

Perlu perhatian pemmerintah daerah Kabupaten Lima Puluh Kota untuk keberlanjutan peningkatan UKM tenun Kubang ini.

\section{UCAPAN TERIMA KASIH}

Program Pengabdian kepada masyarakat melalui skim Program Produk Unggulan Daerah dapat dilaksanakan atas pendanaan Kemenristek DIKTI. Ucapan Terimakasih kepada Kemenristek DIKTI atas pendanaannya

\section{DAFTAR PUSTAKA}

[1] Elida,M., Novita, A,S, Elviati.2015. Laporan IbPE Pengembangan Usaha Rendang Padang Berpotensi Ekspor di Kota Payakumbuh Sumatera Barat. Dibiayai oleh Direkturat Penelitian dan Pengabdian Kepada Masyarakat. Direkturat Jenderal Pendidikan Tinggi. Kementerian Pendidikan dan Kebudayaan, Sesuai dengan Surat Perjanjian Penugasan Program Pengabdian Ipteks bagi Produk Ekspor (IbPE) Lanjutan Batch I. Nomor : 095/SP2H/PPM/DIT. Litabmas /II/3015. Tanggal 5 Februari 2015.

[2] Kartiwa, Suwarti. 1998. Kain Songket Indonesia. Jakarta. Djambatan

[3] Saputra, R. 2015. Budaya Minang, Kesenaian Minang, Tradisi Minang. Diakses www.ranahminang.info/2015/04/songket minang.html

[4] Yulutrip.2014. Pewarna alami untuk tekstil. Blogspot.com.diakses tanggal 15/5/2014. $21 \mathrm{html}$. 